\title{
Zinc Finger and BTB Domain Containing Protein 16
}

National Cancer Institute

\section{Source}

National Cancer Institute. Zinc Finger and BT B Domain Containing Protein 16. NCI

Thesaurus. Code C17918.

Zinc finger and BTB domain-containing protein 16 (673 aa, $74 \mathrm{kDa}$ ) is encoded by the human ZBTB16 gene. This protein is involved in both myeloid differentiation and transcriptional regulation. 